\title{
JEAN-LUC GODARD E O SER DA IMAGEM
}

\author{
JEAN-LUC GODARD AND THE BEEIN OF THE IMAGE
}

\section{JEAN-LUC GODARD Y EL SER DE LA IMAGEN}

Fabiana de Amorim Marcello ${ }^{1}$

\section{RESUMO}

Neste artigo, mais do que investir num modelo de "clássico" como efeito de um lugar originário do discurso cinematográfico, interessa-nos problematizar as categorias que a materialidade do conceito insinua. Para tanto, inicialmente, tomamos como base o trabalho de Foucault para discutir o modo como, na lógica da genealogia e da ruptura, Godard tensiona, de maneira singular, o estatuto sob o qual as suposições acerca do que seria um "criador individual" se sustentam. Em seguida, analisamos alguns materiais produzidos pelo diretor, mostrando que aquilo que caracterizaria Godard como um diretor de ruptura estaria implicado com dois movimentos: primeiro, naquele do rechaço pelo discurso do "diretor" e, segundo, naquele que diz respeito a uma forma de composição sustentada pela busca, incansável, ao que seria a "especificidade" do cinema ou mesmo da imagem cinematográfica. Menos do que sugerir algo que remeta à autenticidade inarredável de um campo, entendemos que Godard opera com a imagem no sentido de sua ausência - e, deste modo, numa necessidade constante de criação não apenas da imagem, mas do próprio conceito de imagem.

PALAVRAS-CHAVE: Godard. Imagem. Cinema. Educação.

\begin{abstract}
In this article, more than investing in a "classical" model as an effect of a place native from the cinema discourse, we are interest in problematizing the categories that the materiality of the concept suggests. To do so, we initially adopted Foucault's work as a basis to discuss the way how, within the logic of genealogy and rupture, Godard singularly tensions the statute on which the assumptions about what an "individual creator" would be are sustained. Next, we analyze some materials produced by the director, showing that what characterizes Godard as a rupture director would be implied in two movements: first, the one of the opposition by the discourse of the "director", and second, the one regarding a way of composition sustained by the tireless search for what would be the "specificity" of cinema or even of the cinema image. Less than suggesting something that alludes to the irremovable authenticity of a field, we understand that Godard works with image in the sense of its absence - and, therefore, in a constant need for creation not only of the image, but of the very concept of image.
\end{abstract}

KEYWORDS: Godard. Image. Cinema. Education.

\section{RESUMEN}

En este artículo, antes que invertir en un modelo "clásico" como efecto de un lugar originario del discurso cinematográfico, nos interesa problematizar las categorías que insinúa la materialidad del concepto. Para ello, inicialmente, tomamos como base el trabajo de Foucault para discutir el modo como, en la lógica de la genealogía y de la ruptura, Godard tensiona, de manera singular, el estatuto bajo el cual se sustentan las suposiciones acerca de lo que sería un "creador individual". Seguidamente, analizamos algunos materiales producidos por el director, mostrando que aquello que caracterizaría Godard como un director de ruptura estaría

\footnotetext{
${ }^{1}$ Doutora em Educação pela Universidade Federal do Rio Grande do Sul, UFRGS, Porto Alegre, RS - Brasil. Professora do Departamento de Estudos Especializados da Universidade Federal do Rio Grande do Sul, UFRGS, Porto Alegre, RS - Brasil. E-mail: famarcello@gmail.com.

Recebido em: 02/04/2016 - Aprovado em: 11/05/2016
} 
implicado en dos movimientos: primero, en aquel del rechazo por el discurso del "director" y, segundo, en aquel que atañe a una forma de composición sustentada por la búsqueda, incansable, de lo que sería la "especificidad" del cine o inclusive de la imagen cinematográfica. Así, menos que sugerir algo que remita a la autenticidad inquebrantable de un campo, entendemos que Godard opera con la imagen en el sentido de su ausencia - y, de este modo, en una necesidad constante de creación no apenas de la imagen, sino del proprio concepto de imagen.

PALABRAS CLAVE: Godard. Imagen. Cine. Educación.

\section{INTRODUÇÃO}

No pequeno e conhecido livro intitulado Por que ler os clássicos, Ítalo Calvino (1993) se propõe a realizar uma tarefa tão complexa quanto curiosa, tão arriscada quanto original. Ora, a uma primeira vista, "por que ler os clássicos" sugere, desde já, uma pergunta cuja resposta, parece, já teríamos; uma conclusão da qual já seríamos sabedores. No entanto, numa escrita econômica e obstinada, Calvino nos mostra que a questão nada tem de óbvia ou previsível. Antes disso, o autor nos conduz a algumas definições bastante precisas que sustentam o que, para ele, mobilizaria nossa leitura a algumas obras que compõem, nada mais nada menos, aquilo de que é feita a história de nós mesmos - ele, logo ele, que também, por que não dizer, seria um "clássico".

No início de seu livro, e dentre as 14 definições dadas ao que seria, afinal, um "clássico", Calvino (1993, p. 14) apresenta uma acepção, de certo modo, transponível - e exatamente por isso ela nos interessa de maneira particular: "um clássico é um livro que vem antes de outros clássicos; mas quem leu antes os outros e depois lê aquele, reconhece logo seu lugar na genealogia". Temos, assim, uma ideia segundo a qual um "clássico" seria algo cuja presença e envergadura emergem na espessura de um "murmúrio anônimo"; algo que se situa no tempo de uma ruptura, instaurada, ela mesma, no jogo dinâmico e constitutivo de e entre continuidades e descontinuidades.

Neste $\operatorname{artigo}^{2}$, mais do que investir num modelo de "clássico" como resultado de um lugar originário do discurso, interessa-nos, justamente, tensionar as categorias que a materialidade do conceito insinua, tentando, para isso, operar no limite entre uma espécie de reconhecimento, mas também de sua problematização. Assim, é, pois, partindo da proposição de Calvino - e da suposição de que ela nos permite compor trilhas em direção a uma discussão sobre aquilo que nos inscreve historicamente na cultura - , que inflexionamos a questão, indagando: afinal, e por que ver os clássicos ${ }^{3}$ ? Mais precisamente, e já apontando para um debate que se efetiva no campo do cinema e da educação, propomo-nos a percorrer elementos que nos indicam a fecundidade na discussão acerca de um diretor - Jean-Luc Godard -, considerando, sobremaneira, os processos de produção de imagens por ele

\footnotetext{
${ }^{2}$ Agradeço ao amigo Luís Henrique Sacchi dos Santos pela cuidadosa leitura da primeira versão deste texto e pelos apontamentos que muito contribuíram para o desdobramento das ideias aqui agora apresentadas.

${ }^{3}$ A pergunta, por certo, não é nova. Aliás, ela já foi feita por outros, ainda que com diferentes abordagens e mesmo de proposição teórico-investigativas. Quanto a isso, saliento, de modo especial, o Ciclo de cinema "Por que ver os clássicos?" - do qual participei, justamente, com uma fala sobre Godard -, organizado em 2012 pelos colegas Amadeu Weinmann, Rose Gurski e Edson Luiz André de Souza, do Instituto de Psicologia da UFRGS.
} 
dinamizados. Se, por um lado, entende-se que suas produções desembocam numa "pedagogia" - a pedagogia godardiana ${ }^{4}$ (DANEY, 1996) -, aqui interessa-nos entender o que, em termos de imagem (cinematográfica), se efetivaria ali como um "clássico" no sentido dado por Calvino, mas também, de algum modo, excedendo-o: ou seja, assumindo por "clássico" algo que se localiza no espaço de um entre - e, com efeito, na continuidade e na descontinuidade de uma criação -, porém entendendo, igualmente, por "clássico" aquilo que multiplica os lugares de produção, de enunciação e de significação.

Por que falar de Godard (e, extensivamente, de um "clássico") no espaço de um entre e naquele de multiplicação (de produção, enunciação e significação)? Porque isso, de algum modo, implica falar de um diretor que, digamos, se torna um "clássico", pois rompe com formas de específicas de ver, com modos particulares de expressão e, acima de tudo, porque, a partir disso, acaba também por erigir, por compor, por propor novas formas de produção da imagem - e, talvez mais do que isso, novas formas de entender o conceito mesmo de imagem no cinema. Daí tornar-se válida uma discussão que se dedique, em alguma medida, à caracterização das bases sobre as quais esta noção de ruptura se sustenta: porque, neste caso, ela nos lança a um lugar a partir do qual nos permitimos, continuamente, perguntar: o que é, afinal, uma imagem? A que ela "serve"? A que tipo de conhecimento ela dá lugar?

Para dar conta destas discussões, este texto está organizado da seguinte forma: inicialmente, pretendemos elaborar uma discussão voltada para a complexificação da noção mesma de "clássico" de acordo com os objetivos do trabalho, neste caso, operando de maneira mais direta com, pelo menos, duas das categorias que ela sugere: autoria e obra. Nosso interesse é debater, a partir de Michel Foucault, os limites, bem como as possibilidades de pensar não a autoria (e a obra) em si mesmas (e, portanto, não a noção de "clássico" em si mesma), mas os efeitos que, em sua combinação, tais conceitos produzem. Para tanto, tomamos emprestado o trabalho de Foucault para afirmar que, na lógica da genealogia e da ruptura, Godard tensiona, de maneira singular, o estatuto sob o qual as suposições acerca do que seria um "criador individual" se sustentam. Em seguida, e como desdobramento desta proposição inicial, buscamos analisar alguns materiais produzidos por Godard ${ }^{5}$, mostrando que aquilo que o caracterizaria como um diretor de ruptura estaria implicado, notadamente, com dois movimentos: primeiro, naquele do rechaço pelo discurso do "diretor" (ou seja, neste caso, paradoxalmente, entendemos que o cineasta produz imagens vinculadas com a negação

\footnotetext{
4 O termo "pedagogia godardiana" foi cunhado por Serge Daney em um artigo originalmente publicado em 1976, no Cahiers du cinéma. Ali, Daney expressa uma ideia segundo a qual Godard opera com o cinema em oposição à escola, ressignificando (e, mais, tensionando) os sentidos usualmente válidos tanto para o espaço stricto sensu da educação, como aquele, possível, da sala escura. Semelhante pressuposto é assumido também por Jorge Vasconcellos (2008), ao sustentar a tese de que o cinema de Godard opera com uma "pedagogia da imagem" uma vez que, em termos deleuzeanos, ali se vê dinamizado um "cinema que pensa", tal como será visto neste texto.

${ }^{5}$ Tal como em Dubois (2004), Vasconcellos (2008), Leandro (2008) e outros, assumimos a título de análise e comentários, menos do que uma marca temporal explícita - que delimitaria uma escolha de filmes a partir de certo período em anos ou mesmo décadas -, um mesmo "movimento de pensamento" (e não o "conjunto da obra", como algo dado), que acreditamos fazer-se presente em grande parte dos filmes do diretor. Nesta condição, tomamos, de modo mais livre, algumas de suas produções mais emblemáticas, considerando, para essa escolha, os pressupostos teóricos que sustentam nossa argumentação.
} 
do sujeito de enunciação emblemático no cinema). O segundo movimento diz respeito a uma forma de composição que se sustenta na busca ao que seria a "especificidade" do cinema ou mesmo da imagem cinematográfica - e isso por meio da proposição de montagem disjuntiva comprometida com um não-saber e com a criação daquilo mesmo que, na imagem, não se pode ver. Assim, menos do que sugerir algo que remeta à autenticidade plena e inarredável de um campo, entendemos que Godard opera com a imagem em seu sentido lacunar, precário ou, mais do que isso, no sentido de sua ausência - e, deste modo, numa necessidade constante de criação não apenas da imagem, mas do próprio conceito de imagem.

\section{NA AUSÊNCIA DO AUTOR, O RASTRO DA LINGUAGEM}

Parece, no mínimo, curioso falar de suspensão da categoria de "autor" (ou de “diretor") justamente quando isso se dá em meio a uma discussão de um dos diretores mais proeminentes de um movimento que levou o título de "política dos autores" (politique des auteurs), e que teve seu auge entre as décadas de 50-60 na França. Mais curioso ainda é quando, sabemos, tal movimento visava, acima de tudo, a afirmação do diretor-autor, a inscrição decisiva dessa figura na produção de "seu" cinema e a defesa de que algo ali se processava exclusivamente pela via de um sujeito eminentemente criador. Além disso, na esteira de uma relação que reivindicava a primazia do diretor e tudo que nele se retém (inclusive, a ideia de um "clássico", em seu sentido mais recorrente), é válido lembrar que Godard fez parte do grupo de Dziga Vertov, na composição de um cinema comprometido em desvendar, pelas mãos daquele que cria com e a partir da câmera, a verdade e a ética envolvidas em um sistema de exploração material urdido pelo capitalismo. Ao dizer isso, não negamos o fato de que "Godard" não é um nome qualquer. Ou, talvez mais, não negamos o fato de que Godard é um diretor que concentra, a partir da crítica mais ampla que o define, a solidez de algumas das categorias que buscamos problematizar.

Tais considerações nos levam ao cerne de uma das mais emblemáticas discussões elaboradas por Michel Foucault: aquela que evidencia que o autor não é um nome próprio como os outros; ele é, antes, o "equivalente a uma descrição" (FOUCAULT, 2001, p. 272). Ao dizer isso, Foucault estava empenhado em mostrar que a figura do autor está diretamente relacionada com os sentidos que os textos (e seus correlatos) produzem - no limite, antecipando-os e excedendo-os. A solenidade de afirmar que "isso foi escrito por tal pessoa" e, extensivamente, "isso foi produzido por tal diretor", ou, ainda, que este ou aquele é da ordem de um "clássico", nos dá indícios muito concretos de que de não se trata de um movimento indiferente, prosaico, mas que, ao fazê-lo, também aqui, no campo do cinema, conferimos certo status tanto a um sujeito, como àquilo que dele deriva (ibidem).

Nesta perspectiva, entendemos que nome e obra não são apenas, ambos, termos isolados, mas unidades mutuamente constitutivas, que se remetem reciprocamente, compondo-se, articulando-se e definindo-se relativamente uma à outra. $\mathrm{O}$ nome do autor opera nos textos: "ele os recorta, segue suas arestas, manifesta o modo de ser ou, pelo menos, os caracteriza" (FOUCAULT, 2001, p. 274), ele instaura uma certa rede de inteligibilidade a partir da qual os recebemos. Da mesma forma, os textos (ou, em seu conjunto, a "obra", 
termo tão proclamado, como pouco tangenciável) operam sobre o autor: eles convidam a nos reportarmos a uma individualidade, a uma biografia como algo a ser explicado e ali tornado visível, a algo que responderia a um princípio de expressão de um pensamento (FOUCAULT, 2000a). Em suma, no sentido mais usual dos termos, o autor diz da obra tanto quanto a obra diz de seu autor. Nesta perspectiva, podemos afirmar que o autor é entendido não apenas como mero elemento do discurso, mas como algo que exerce certo papel em relação ao discurso, atuando, nos textos, na obra, como princípio organizador, como fundamento de coerência e mesmo de transparência (FOUCAULT, 2001).

Ao propor estas discussões, Foucault problematizava as relações que historicamente estabelecemos com aquilo a que convencionalmente chamamos de "obra", bem como com esta figura a que damos nome de "autor", tensionando a contiguidade entre uma e outra, sobretudo quando pautadas sobre algumas dimensões de análise que tão bem reconhecemos, como, por exemplo, aquelas que remetem ao jogo da "interpretação" e ao discurso de uma "origem". No viés da "interpretação", nos situamos, muitas vezes, frente à tentativa de recuperar, naquilo que é dito, um "não-dito"; supomos uma "voz silenciosa", uma palavra manifesta que paira sobre os textos, aquela mesma a ser descortinada (FOUCAULT, 2000b, p. 91). O discurso de uma "origem", no caso da análise sobre o autor, remeteria, por sua vez, à tentativa de capturar "a essência exata da coisa" (idem, 2000c, p. 262) no espaço deixado pelo sujeito autônomo, da razão, senhor de sua consciência. Neste caso, a análise se vê presa a um princípio antropológico, sendo a racionalidade o princípio teleológico que a justifica.

Considerar tanto o "autor" como aquilo a que a ele remete diretamente - a "obra" nos conduz a caracterizar o papel decisivo que ambos exercem entre si, mas, ao mesmo tempo, significa também apontar para sua precariedade. Dizendo de outro modo, para Foucault, tratava-se de afirmar que tais categorias podem ser questionadas ou, mais do que isso, que "devemos sacudir a quietude com a qual as aceitamos" (2000a, p. 29). Afinal, como resumir, peremptoriamente, o que define uma obra? E, sobretudo, o que é isso a que chamamos de "autor"? Nesta condição, a démarche foucaultiana estaria sustentada pela problematização da própria categoria de sujeito e, mais precisamente, daquilo que se erige por meio das grandes unidades que nos definem, nos explicam e nos constituem - algo que já vinha, inclusive, sendo efetivado em alguns de seus trabalhos anteriores ${ }^{6}$. Problematizar a categoria de sujeito (aquele da "origem", da razão), bem como destas unidades, consistia em estabelecer outros níveis de investigação, que, por sua vez, convocavam, no lugar de sua adoção imediata, à pergunta sobre seus limites, sua legitimidade e sua definição: "O que é uma obra? O que é uma ciência? O que é uma teoria? O que é um conceito? O que é um texto?" (FOUCAULT, 2000a, p. 6, grifos do original). Assim, a questão "o que é um autor?" não apenas dá nome a um de seus mais célebres textos, como se faz, ela mesma, interrogação direta a um dos muitos nomes assumidos pelo conceito de sujeito.

\footnotetext{
${ }^{6}$ De modo, talvez, mais emblemático, é em As palavras e as coisas (1999) que Foucault, ao analisar as bases sobre as quais a episteme moderna se erige, dedica-se a descrever a emergência do homem como sujeito e como objeto de conhecimento. Ao fazer, portanto, a história destas práticas, o autor, ao mesmo tempo, coloca-as em questão, justamente por sinalizar, em relação à noção de sujeito - e, com efeito, de sujeito da razão -, sua recente invenção.
} 
Por certo, trabalhar com um diretor como Godard implica caminhar por esta linha perigosa que contorna e sustenta a afirmação do estatuto do autor. Por certo, aliás, sempre que convocamos um autor (ou diretor) a ocupar o palco de um debate, nos colocamos frente a ela. No entanto, nosso interesse envolve o trabalho de tentar, de algum modo, ainda que limitadamente, "dobrar" esta linha, fazer com que ela componha outras relações, engendre outras associações. $\mathrm{O}$ esforço, portanto, é teórico-metodológico, sobretudo àqueles que, no campo da educação, se empenham em análises cinematográficas e, por vezes, se colocam frente a tais definições, sem apagá-las, mas também sem assumi-las por completo. Ou seja, não se trata de fortalecer as unidades que a erigem por meio de um estudo sobre a singularidade privada de um diretor; não se trata de, a partir dele, realizar uma espécie de "genealogia de sua individualidade" (FOUCAULT, 2001, p. 286-287). O trabalho aqui, isso sim, relaciona-se ao convite lançado por Foucault, a quem não basta dizer que o autor, como unidade fixa e definida, não existe, mas aquele de "localizar o espaço deixado vago pela desaparição do autor, seguir atentamente a repartição das lacunas e das falhas, espreitar os locais, as funções livres que essa desaparição faz aparecer" (ibidem, p. 271). O que isso significa? Significa que, neste texto, operamos com Godard a partir de duas chaves de leitura: uma que consiste em entender que o que diretor produz, em seus materiais, pode ser analisado pelo viés do desaparecimento de uma interioridade. Nos termos foucaultianos, então, diríamos que ele "despista todos os signos de sua individualidade particular" (ibidem, p. 269). Outra, voltada não para a proposição de uma imagem comprometida com a ordem do significado, mas para aquilo que a suspende enquanto tal, operando pela disjunção, pelo indiscernível e pelo rechaço ao que liga a imagem ao exercício de uma recognição.

Antes de passarmos imediatamente à caracterização destes procedimentos, importa, ainda, destacar alguns elementos sobre este "lugar vazio" deixado pelo autor de que fala Foucault. Neste sentido, é preciso considerar que as discussões sobre "o que é um autor?" e, mais amplamente, aquelas tratadas em seus estudos sobre a literatura, baseavam-se, sobremaneira, na leitura e na análise de uma materialidade específica: a da palavra como gesto de escrita. O que fazemos neste texto, então, não é a mera e imediata equivalência entre as possibilidades da literatura e aquelas do cinema, mas, ainda que guardadas as diferenças de cada campo (e, sem dúvida, de cada discussão), é uma tentativa de operar sobre os pressupostos que permitiam Foucault estabelecer aquilo que seria uma experiência singular. São, pois, estes pressupostos que nos permitem adentrar num domínio semelhante àquele sobre o qual o filósofo realizou sua análise: o da crítica à representação, à fixidez da linguagem entendida como expressão, como verdade, seja de um mundo que lhe seria exterior, seja de um sujeito na condição de inabalável enunciador. Entendemos que tal movimento é possível porque, no cinema, se opera com outro elemento fundante da representação nestes mesmos termos, qual seja, o domínio da imagem. Na inseparabilidade entre conteúdo e forma que marcaria este (outro) modo de entender a linguagem, o que nos permite fazer esta aproximação é o fato de que, também aqui, trata-se de situar a imagem para além dos limites que o fim da representação e da comunicação de um sentido lhe impõem, não expressando, com efeito, nenhuma realidade preexistente. 
Ora, se Foucault procedeu a uma leitura e a um estudo sobre autores como, e para citarmos apenas alguns, Mallarmé, Artaud, Blanchot e Roussel para indicar uma certa forma de ser da linguagem, não foi para ali celebrar as categorias de autor e de obra nos termos da soberania do sujeito ou da significação dos signos. Antes disso, pode-se dizer que o interesse na proposição singular de literatura que Foucault via nesses autores estava radicado na interrogação sobre a palavra literária quando e na exata medida em que aberta a uma linguagem que não remete nem a um sujeito, nem a um objeto; a uma linguagem erigida em direção à exterioridade de uma subjetividade. Machado afirma, inclusive, que entender a experiência da literatura ou a literatura como experiência implicava, para Foucault, "ultrapassar a oposição entre interioridade e exterioridade, entre sujeito e objeto", e isso pela experiência da obra, da obra como experiência (MACHADO, 2005, p. 113). O que isso sugere? Sugere situar-se no "caráter bruto, selvagem, enigmático da palavra, em detrimento dos funcionamentos representativo e significativo da linguagem" (ibidem, p. 109). São esses pressupostos, então, que definem a análise tal como propomos, e que convergem, talvez, para uma compreensão do ser da imagem, em Godard. Trata-se de pressupostos que exigem um deslocamento do olhar, partindo não do que a palavra e, igualmente, a imagem "significam", mas, antes, do trabalho de perscrutar suas modalidades de existência, naquilo que permitiria sancionar uma concepção de linguagem em "seu ser informe, mudo, não-significante" (ibidem, p. 112).

\section{NO RASTRO DA PALAVRA, A IMAGEM}

O universo da palavra, como gesto de escrita, foi marca constante no trabalho e na vida de Godard. Como crítico de cinema no antológico Cahiers du cinéma (antes mesmo de tornar-se diretor), como amante da literatura, como diretor que promoveu, de diferentes modos, as mais intricadas e variadas relações entre a imagem e o espaço literário. A relação mutuamente constitutiva entre texto e imagem deu margens a diferentes tipos de operações, que respondiam a diferentes pressupostos e, com isso, faziam variar não apenas a matériapalavra (na qualidade de objeto), mas a forma-sujeito de sua enunciação. Deste conjunto de operações, emerge uma relação tão produtiva quanto paradoxal no que se refere ao tipo de imagem que suas produções colocam em jogo: aquela que "reinvidica, ao mesmo tempo, o amor às palavras e sua desconfiança para com elas" (DUBOIS, 2004, p. 260).

Assim, interessa-nos assumir um primeiro eixo de análise, qual seja, aquele que remete à "presentificação do texto nas e pelas imagens" (DOUBOIS, 2004, p. 260), uma vez que, por meio disso, entendemos que o diretor dinamiza, a um só tempo, dois movimentos: o da multiplicação do sujeito enunciador e, com isso, um segundo, a desestabilização da categoria de diretor. Ao propor um tipo particular de experimentação com a imagem sustentado por esses dois movimentos, tem-se, com efeito, novas configurações sobre os modos de ver, novas problemáticas em relação à constituição mesma da imagem.

Falamos de uma "desconfiança" para com as palavras na medida em que, em Godard, a composição da imagem se faz, em grande parte, mediante a recusa daquela que seria a "palavra de ordem" do cinema: o roteiro. Ao colocá-lo sob suspeição, compõe-se em seus 
filmes uma questão, no limite, filosófica com a qual se problematiza as práticas que incidem sobre o ato de ler como anterior ao de ver, sobre a consecutividade (e ilusória contiguidade) entre o escrito e a imagem que, a partir dele, se produz. Falamos, pois, de um cineasta que não cansou de proclamar que "o escrito é seu 'inimigo real', que é preciso 'ver e não ler', que a escrita é a Lei' e, portanto, 'a morte' [...]" (DUBOIS, 2004, p. 260). Assim, no cinema de Godard, cabe inscrever a palavra escrita em outro regime de linguagem, cumprindo outra função que não a de ser obedecida: "não imagens justas, mas justo imagens", como sugere um de seus mais célebres enunciados.

Excertos de textos literários, letreiros, painéis; fragmentos de cartas, cartões-postais, jornais; capas de livros, panfletos, letreiros, pichações e grafites. Escrever frente à (e na) tela, ler em voz alta, narrar enquanto se escreve. Das mais diferentes formas, e respondendo a diferentes pressupostos, Godard foi e é incansável na produção de uma imagem e de filmes como matérias a serem percorridas, lidas, e não somente vistas (DUBOIS, 2004). Do enunciado à enunciação, do universo da palavra como objeto fílmico àquele no qual ela se trama como e na própria matéria-filme (ou seja, de uma questão diegética àquela que a ultrapassa), uma estética singular convoca um olhar instável, dinamizado por um constante entrar e sair da imagem cinematográfica.
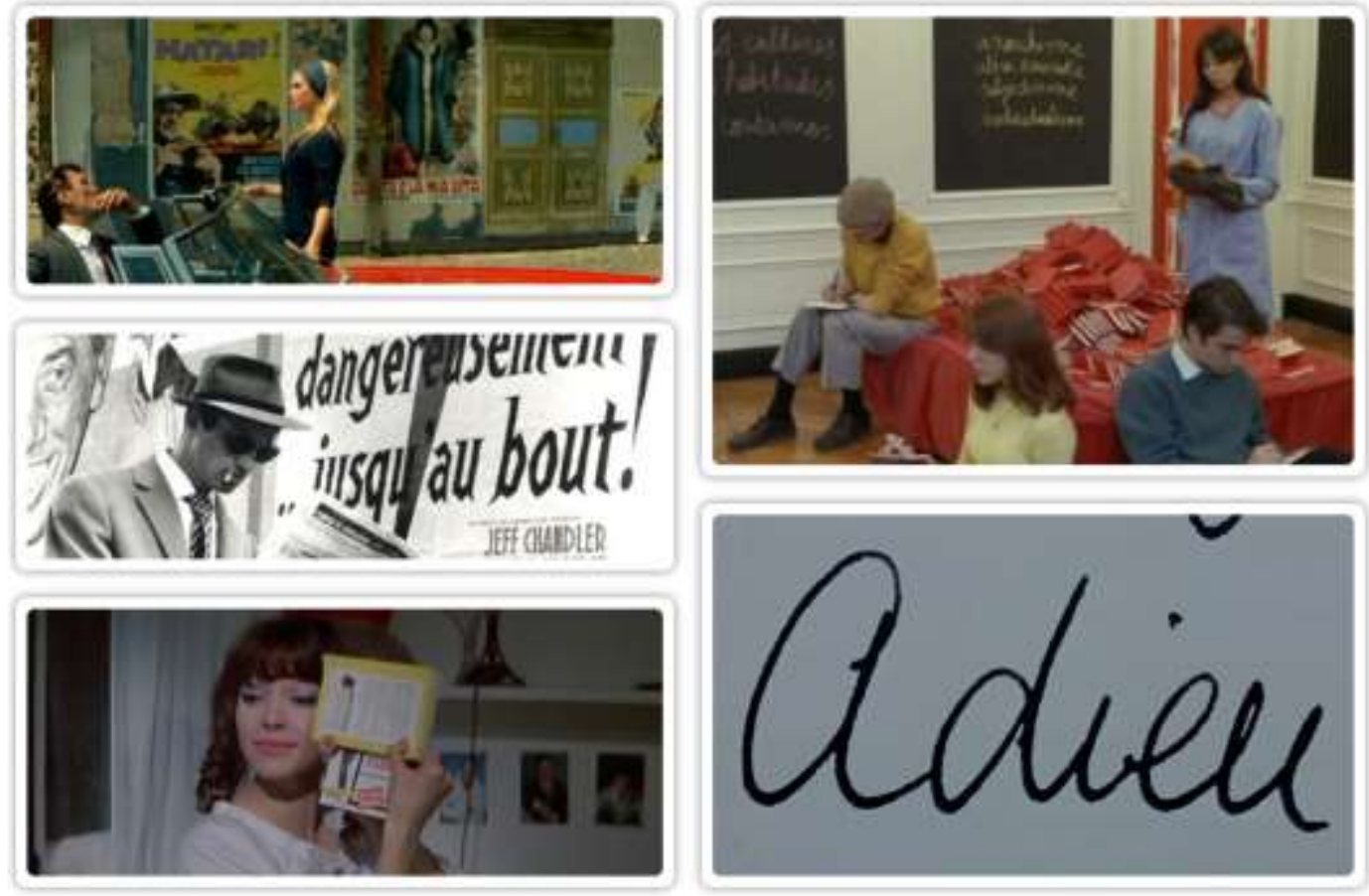

No sentido horário, Imagem 1: $O$ desprezo (1963); Imagem 2: A chinesa (1967); Imagem 3: $O$ desprezo (1963); Imagem 4: Uma mulher é uma mulher (1961); Imagem 5: O acossado (1960).

No espaço em que visível e legível concorrem ${ }^{7}$, o excerto do romance enunciado diretamente à câmera, o slogan da propaganda e as exortações militantes ocupam um e mesmo lugar - talvez sem necessária hierarquização, já que o que está em questão é a

\footnotetext{
${ }^{7}$ Imagem 1 - Fonte: $<$ http://goo.gl/ZpJUyC $>$; Imagem 2 - Fonte: $<$ http://goo.gl/hPn4f2 $>$; Imagem 3 - Fonte: $<$ https://goo.gl/y7fUoa >; Imagem 4 - Fonte: $<$ http://goo.gl/twXaKG>; Imagem 5 - Fonte: $<$ http://goo.gl/IEBgxS $>$.
} 
tessitura enigmática da imagem, que tensiona, a todo o tempo, o que está dentro e o que está fora dela (ou, em outras palavras, o real e o ficcional). Em $O$ desprezo, temos a célebre frase dos irmãos Lumière ("O cinema é uma invenção sem futuro") como pano de fundo, ironicamente, de uma discussão sobre o ato de filmar. Aliás, o próprio filme tem como tema a adaptação para o cinema da Odisseia, de Homero - já que é esta a questão primeira do livro $I l$ Disprezzo, de Alberto Modavia, da qual o filme de Godard ( $O$ desprezo) é uma adaptação. O filme (Odisseia) dentro do livro (de Moravia) que, por sua vez, está dentro do filme (de Godard). Tal como em Borges em "O jardins dos caminhos que se bifurcam" (1989), neste caso, a imagem é, ela mesma, o próprio labirinto. Reduplicar a linguagem constitui-se, no cinema de Godard, como o próprio ser da linguagem ou, mais propriamente, o próprio ser da imagem: abertura involuntária na qual a linguagem e a imagem constantemente falam de si mesmas.

A presentificação do texto da qual falamos se dá, ainda, sob a forma de uma recusa: aquela das soluções da ordem da escrita para as perguntas que se colocam no domínio da
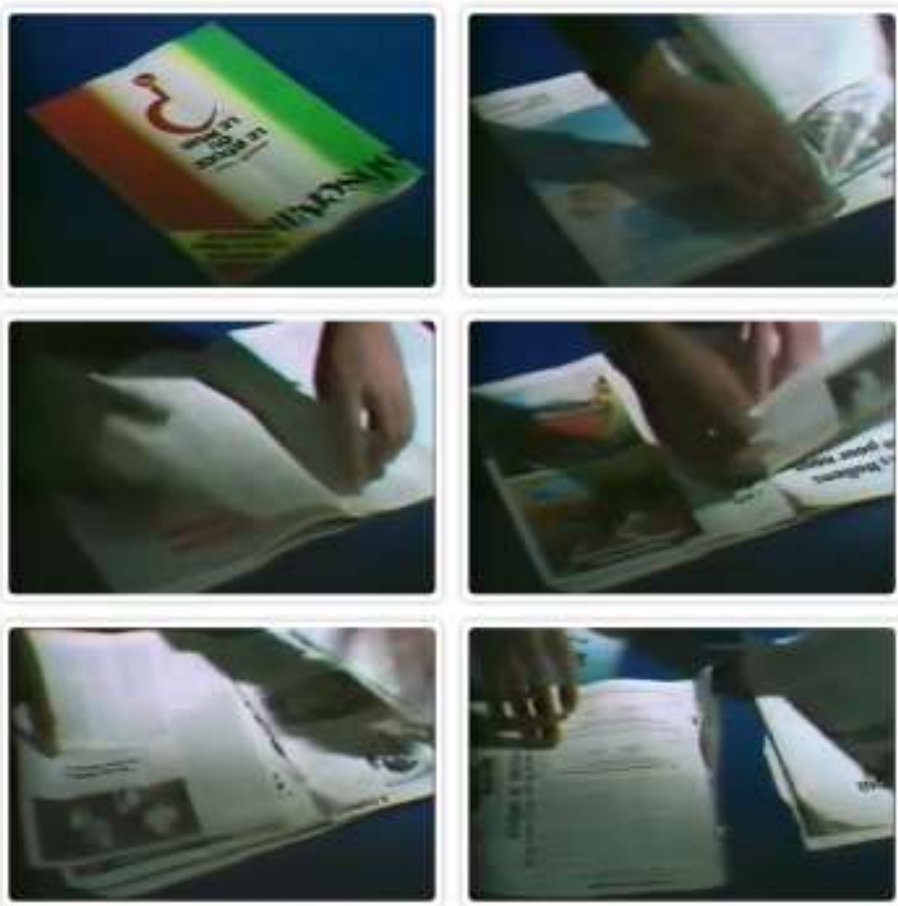

Fotogramas extraídos livremente e em sequência direta de Six fois deux (1976). imagem. Sem os recursos da metáfora e da metonímia, por exemplo, tão frequentes na criação de imagens no cinema, resta ao cinema operar diretamente sobre a matéria bruta do mundo, abrindo mão de fórmulas de criação prontas; resta ao cinema literalizar - ou, mais propriamente, fazer ver. $\mathrm{Na}$ criação da imagem, não há, portanto, espaço para figuras de linguagem - entendidas, notadamente, como marcadores de análises textuais: são as palavras que devem se projetar sobre as imagens, e não o contrário. Isso porque, no conceito de imagem (cinematográfica) aqui em jogo, não cabe a pretensão de um sentido universalizante, mas aquele que a singulariza enquanto tal. Como no exemplo dado por Deleuze (1990, p. 220), extraído de Six fois deux, parece muito pouco dizer que, sem as propagandas publicitárias, uma revista não se sustenta, "não fica de pé", é preciso mostrar isso; mais uma vez, fazer ver. 
Esta marca (repetível) - da presentifição do texto - diz respeito, primeiro, ao fato de que, mais do que meras citações provindas dos mais distintos meios (curiosamente, sem autoria, sem as fontes de onde são retiradas), indicamos um processo que instaura uma imagem como resultado de uma "massa discursiva", de uma "colagem" (VASCONCELLOS, 2008, p. 163), em suma, uma imagem-trama, imagem-apropriação, imagem-antropofágica. O que resulta disso é a suspensão do discurso único já que, nesta condição, os personagens, o cenário, e o próprio gênero fílmico compõem, ou pelo menos manifestam, uma linguagem tão difusa quanto enigmática: afinal, o que faz parte da imagem na qualidade de "cinematográfica"? Quem é seu sujeito enunciador, senão um lugar vazio, prestes a ser ocupado indefinidamente? O que se vê nessa "massa discursiva", assim, é a presença de intercessores por meio dos quais torna-se possível pensar um cinema para além da autoria, para além da forma-Eu, já que parece afirmar, continuamente, e seguindo Rimbaud, o "Eu é um outro"” (DELEUZE, 1990, p. 226; VASCONCELLOS, 2008, p. 162).

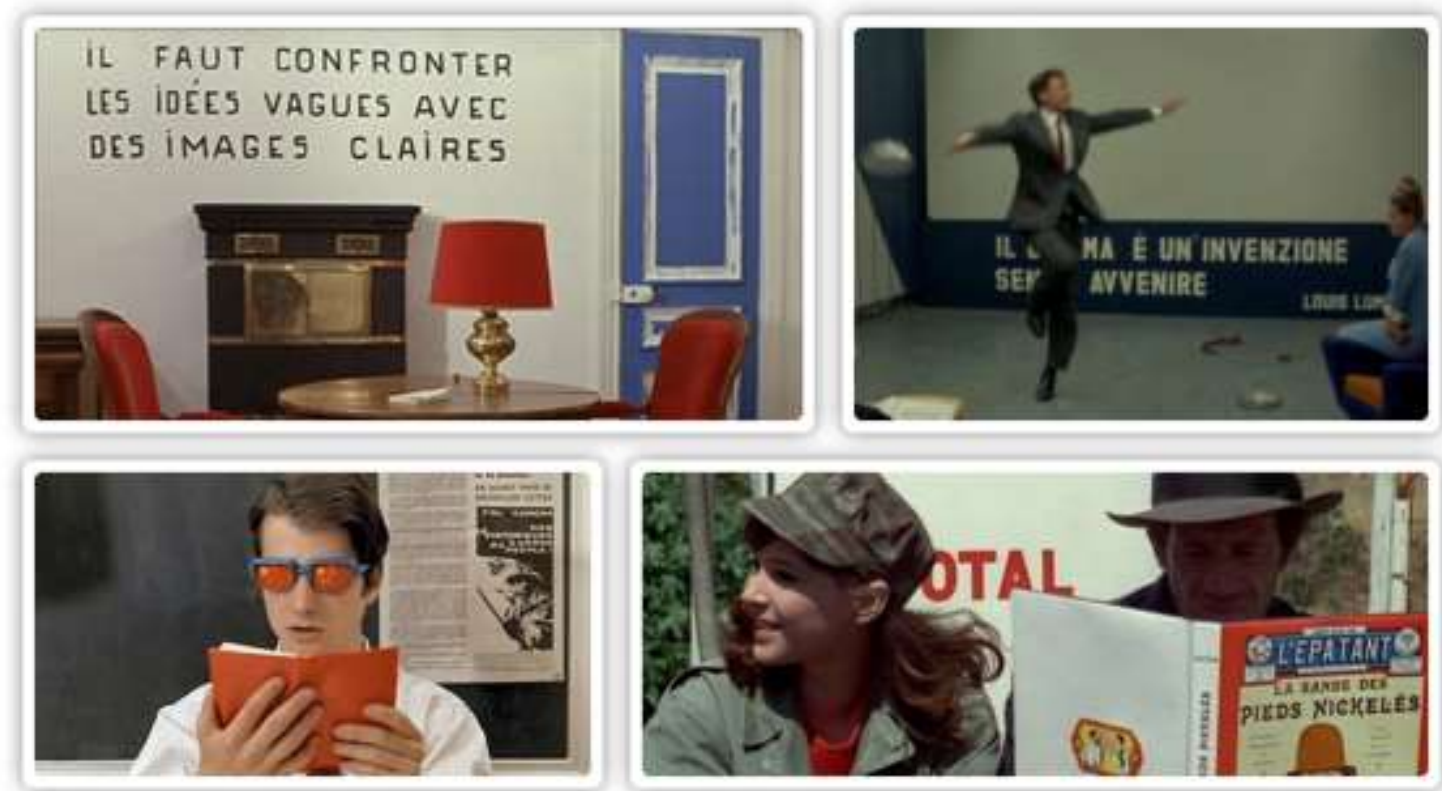

No sentido horário, Imagem 1: "É preciso confrontar ideias vagas com imagens claras", $A$ chinesa (1967); Imagem 2: Em italiano: "O cinema é uma invenção sem futuro", em $O$ desprezo (1963); Imagem 3: A chinesa (1967); Imagem 4: O demônio das onze horas (1965).

No "cinema-pop" (VASCONCELLOS, 2008, p. 163) que caracteriza aquele de Godard, então, uma e mesma marca parece se sustentar: aquela de uma imagem habitada por múltiplos exteriores e múltiplos tempos. O próprio sentido de pop deriva também de um elemento fundamental, que implica a garantia da imagem em sua marca de dinamicidade, multiplicação e dispersão. Tal como Foucault analisa em relação ao caráter pop das fotografias-pinturas de Fromanger, o que se faz aqui é, de modo semelhante, "assegurar o trânsito das imagens", fazer da imagem um incontornável plural: imagem como "funda de imagens" (FOUCAULT, 2001, p. 352).

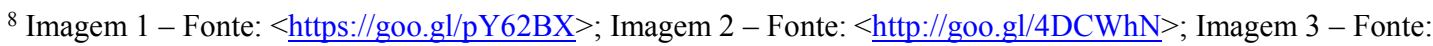

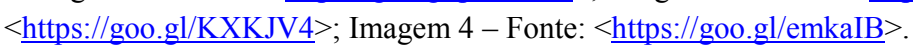


O que resulta da opção pela trama, pela apropriação é a emergência de uma imagem que nada comprova, já que, muitas vezes, o que vem antes e mesmo depois dela não serve senão para sua desestabilização. A presentificação do texto nas imagens, dá a ver, assim, um caráter de disjunção, de dissonância e de estranhamento - algo que sustenta, aliás, um dos elementos da "pedagogia godardiana", tal como proposta por Daney (1996):

\begin{abstract}
O já-dito-por-outros coloca-nos diante do fato consumado; ele deve existir, consistir. Por sua existência, ele torna ilusório qualquer procedimento que tentaria restabelecer atrás, na frente, em torno dele, um domínio da enunciação. Aos enunciados que acolhe, Godard nunca coloca sua condição de possibilidade, o lugar de onde eles obtêm sua legitimidade, o desejo que eles traem e defendem ao mesmo tempo. Seu procedimento é o mais anti-arqueológico possível. Consiste em tomar nota do que é dito [...] e a procurar logo o outro enunciado, o outro som, a outra imagem que poderia vir a contrabalançar esse enunciado, esse som, essa imagem. 'Godard' não seria senão o lugar vazio, a tela preta na qual imagens, sons, viriam coexistir, se neutralizar, se reconhecer, se designar, em suma: lutar (DANEY, 1996, p. 88 , tradução nossa, grifos do original).
\end{abstract}

O sentido de "luta" apontado por Daney se efetiva, justamente, pela relação em nada pacífica que as imagens e as palavras (escritas), na condição aqui destacada, mantêm entre si. Ao contrário, na ausência de encadeamentos que pressuporiam complementariedade, há uma
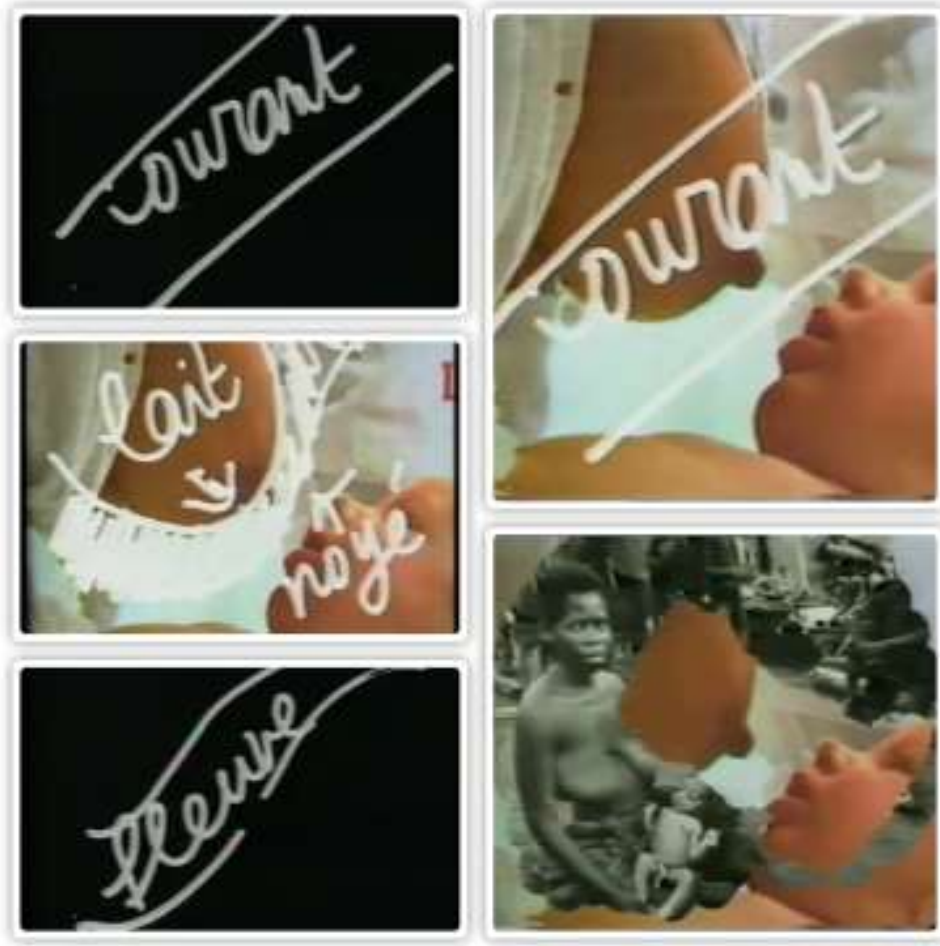

Fotogramas extraídos livremente e em sequência direta de Six fois deux (1976). permanente tensão entre imagens e palavras: o uso do trocadilho, da palavra projetada que se apaga, pouco a pouco, e transforma em outra (para derivar, às vezes, numa terceira ou quarta) são frequentes e seu filme mais recente, Adeus à linguagem (2014), é mostra disso. De enunciados solitários que se deformam, se decompõem, se fazem e se refazem no objetoimagem à incrustação, sobreimpressão, inscrição da palavra escrita na tela, diante de nós, tem-se uma relação agonística entre as imagens, as quais, menos que responderem a um encadeamento racional, se fazem disjuntivas no "palimpsesto cinegráfico" (DUBOIS, 2004, p. 271). A imagem-texto emerge, assim, como lugar da interrogação - e não como irremediável comprovação, "ilustração" de algo que a designa. O que resulta disso é que o sentido da imagem-texto é hesitante, lacunar e, no limite, efêmero, já que ele se forja e se dissipa continuamente. $\mathrm{Na}$ imagem-texto, portanto, nada "significa", nada corresponde a [alguma coisa]: fazer-se, ela mesma, fronteira, limite é o ser mesmo da imagem em Godard. 
$\mathrm{Na}$ inseparabilidade entre conteúdo e forma - ou, mais precisamente, entre arte e técnica - que garante a particularidade da imagem tal como discutida, merece destaque o fato de que a produção plástico-estética deste tipo singular de imagem-trama, imagemapropriação de que falamos ganha sua radicalidade os trabalhos em vídeo produzidos pelo cineasta, na década de 709: de Aqui e acolá (1974), Numéro deux (1975) e Como vai você (1978) às produções Six fois deux (1976) ou mesmo Tour / detour / deux enfants (1977-1978). Menos do que mera "fase" no percurso do diretor, a produção destes materiais (a princípio, inclusive, feitos para serem veiculados na televisão) indica o modo como, por distintos meios (aqui, o vídeo, o uso da light pen ${ }^{10}$ para escritas direto na tela) algumas problemáticas fundamentais são desenvolvidas - o que, de fato, não deixa de ser visível no já citado Adeus à linguagem (2014), no qual o diretor se vale, por exemplo, de câmeras de celular para a captação e invenção de um tipo particular de estética da imagem. Não se trata de mera "evolução", mas da insistência em fazer da linguagem cinematográfica uma pergunta permanente: "Ah, Dieu", "oh, language", como sugere os movimentos que transformam o título do filme, por meio da imagem em 3D na abertura. O meio técnico não é mero suporte para o cinema; ele é, antes, possibilidade de criação de uma nova tessitura imagética e, com efeito, estética. Insistimos, não se trata apenas de um "avanço" técnico, mas de uma construção que faz avançar as margens de novas singularidades da imagem cinematográfica tal como o som, na história do cinema: menos do que elementos então "novos", capturáveis mediante tecnologias que então se ampliavam e se ampliam, trata-se daquilo que torna o cinema, cinema. É isso, aliás, que faz de Godard um diretor - certamente, ainda hoje - em busca permanente de uma "ontologia da imagem cinematográfica" (LEANDRO, 2001, p. 62).

\section{NO RASTRO DA IMAGEM, O NÃO-SABER}

Os trabalhos sobre cinema desenvolvidos por Deleuze (1990; 1983), sem dúvida, trouxeram leituras singulares sobre os filmes (e as imagens) de Godard. No que diz respeito à discussão aqui proposta - que aponta para o "espaço vazio" deixado pela ausência do diretor na qualidade de enunciador privilegiado -, pode-se afirmar que, para o filósofo, a potência do cinema godardiano se concentraria, em alguma medida, na proposição de um método específico: o "método do entre" (1990, p. 217, grifos do original). Por meio dele, e no lugar da cadeia de imagens, escravas umas das outras em proveito ao que se dá o nome de continuidade, são oferecidos o corte, a fratura, a ruptura, a vertigem. Ou, mais propriamente, em Godard, não se trata de sujeitar a continuidade (entre as imagens) a uma lógica racionalizante - e, portanto, confortadora -, mas a algo somente possível porque, entre elas, há, insistentemente, uma fronteira, um limite que marcam, de forma indelével, a

\footnotetext{
9 É válido mencionar que, no Brasil, apenas mais recentemente, com a popularização de sítios de compartilhamento de vídeos, como o Youtube e Vimeo, tais materiais podem ser facilmente encontrados. Por certo, o acesso a estas produções hoje vem preencher uma importante lacuna, já que as frequentes menções a eles - como é o caso das discussões deleuzeanas sobre o diretor, por exemplo - soavam, até pouco tempo, como espécie de incógnitas.

${ }^{10}$ Popularizada na década de 80 , a light pen, como a própria tradução sugere, corresponde a uma caneta ótica que permite com que se possa escrever diretamente sobre a tela - semelhante ao que hoje se faz diretamente com o toque (touch sreen) em aparelhos como celulares, tablets, etc.
} 
desestabilização do olhar, e que sustentam e são sustentados por relações da ordem do impensado. Com efeito, é o fato de quebrar a lógica (inclusive) da sucessão, da separação entre o antes e o depois, ao conciliar "o antes e o depois num devir", que permite Godard produzir uma imagem-tempo (DELEUZE, 1990). Assim, menos do que anular a distância entre uma imagem e outra - criando, pela montagem, um mesmo sentido que apenas progride, se complexifica e, portanto, se conserva -, trata-se de fazer do filme (ou do vídeo) um campo avesso ao voyeurismo imperturbável, no qual o valor absoluto da imagem pouco (ou nada) importa, mas, antes, apenas acena para um vestígio.

Mais do que isto: este método permite a Deleuze afirmar que Godard afasta-se do primado do é (do ser) para situar-se no domínio da conjunção "e"; afasta-se, então, do primado da totalidade em direção àquele da multiplicidade. $\mathrm{O}$ que se tem aqui é a aposta aguda do "e" como motor que faz agir a diversidade, a fratura das identidades, a multiplicidade (DELEUZE, 2000, p. 60). A questão não é garantir que uma imagem é (seja) isto, mas a do apelo a uma imagem $e$ mais outra $e$ mais outra - "isto e aquilo" (DELEUZE, 1990, p. 217). No interstício, no espaço que, então, se inscrevem o inesperado e a lacuna, o sujeito do olhar é convocado a situar-se como uma espécie de exterior da imagem. Assim, compreende-se que não há valor absoluto na/da imagem, mas que é justamente a relação mesma que as imagens estabelecem entre si que permite a construção de algo outro, fora das mãos do diretor. Qualquer possibilidade de uma imagem ser alguma coisa, definível e definitiva, de ela corresponder a uma coisa fixa, vê-se, então, suspendida, já que, na associação entre uma imagem e outra, o que menos é buscado é a atração óbvia entre si, mas a escolha pela divergência, por aquilo que, entre elas, impõe uma resistência. Por extensão, então, diríamos que o ser da imagem em Godard é, no entanto, e com a ousadia do paradoxo, pura multiplicidade; o ser da imagem é ser dois (GODARD, 2000).
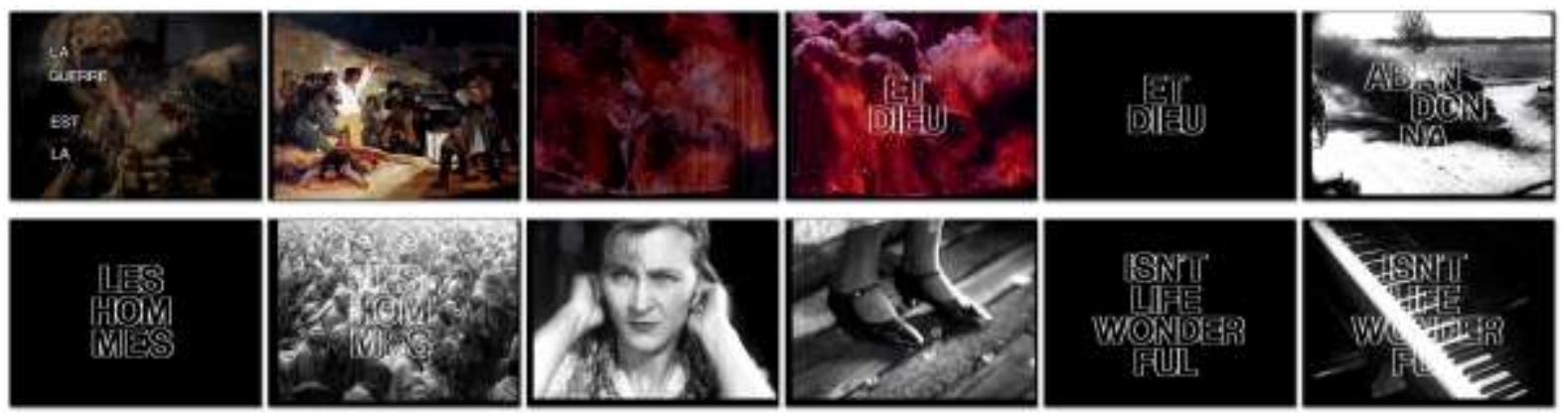

Fonte: Fotogramas extraídos livremente e em sequência direta do filme Histoires(s) du cinéma [1988-1998].

Por que exatamente a potência do cinema godardiano se concentraria nisto? Porque é por meio da produção de uma imagem que se dá no interstício que o cinema pode produzir problemas. Falamos, neste caso, do problema da ordem que relega a imagem ao domínio da informação, da interpretação, daquele acerca de uma verdade que, por trás da imagem, se esconderia, ou que, à sua frente, se revelaria. Nesta condição, portanto, o cinema de Godard produz pensamento - ou, nas palavras de Vasconcellos (2008, p. 155), organiza, por meio do pensamento que suscita, um tipo singular de pedagogia: uma "pedagogia da imagem". Entende-se, portanto, que "a verdade das imagens não está na imagem mostrada na tela, mas \begin{tabular}{l|l|l|l|l|l|l} 
(C) ETD - Educ. Temat. Digit. & Campinas, SP & v.18 & n.2 & p.437-457 & abr./jun.2016 & ISSN 1676-2592
\end{tabular} 
na junção entre elas, melhor dizendo, no que se dá a ver entre as imagens" (VASCONCELLOS, 2008, p. 163) e, acrescentamos, uma verdade muito pouco capturável e definível, já que sua construção é lançada para aquele que assiste; já que ela corresponde, nada mais nada menos, e como já referido, a um vazio.

As discussões que Deleuze produz sobre o cinema de Godard são visivelmente ampliadas por aquelas que, mais recentemente, Didi-Huberman (2003; 2015) vem desenvolvendo, sobretudo no que diz respeito precisamente ao conceito de montagem com o qual opera o diretor. Mais diretamente, o filósofo analisa uma produção específica de Godard na qual, talvez, este modo de operar com as imagens em suas fronteiras seja mais visível: Histoire(s) du cinéma [1988-1998] - um filme de quatro horas e meia, dividido em quatro capítulos, em que, como o próprio título sugere, Godard revisita (ou melhor cria) a(s) história(s) do cinema. Imagens de arquivo (de filmes, fotográficas, jornalísticas, de pinturas, da publicidade) somam-se às de vídeo-escrita, às citações literárias, a efeitos sonoros, à música clássica, a diálogos e trilhas de filmes para trazer ao cinema uma história que o excede: a história do cinema é, aqui, tanto singular como plural, diversa, já que, nela, é a própria história do século XX que se inscreve, em sua beleza e em seu horror. Histoire $(s) d u$ cinéma torna-se, então, um filme emblemático, pois dinamiza elementos fundamentais sobre a discussão relativa ao conceito de imagem. As imagens, nesta produção, se abrem, se dilatam, se expandem para receber toda a espécie de traço e de vestígio. Menos do que superfícies sólidas, as imagens são, antes, porosas, permeáveis; são um campo suscetível à contaminação.

O que Deleuze chama de "método do entre" aproxima-se do que Didi-Huberman (2003, p. 157) identifica como "montagem centrífuga": "um tipo de montagem que faz turbilhar os documentos, as citações, os fragmentos de filmes em direção a uma extensão jamais preenchida”. Didi-Huberman, no entanto, não se resume a atentar para algo que, como vimos, Deleuze já o fez: ele, antes, desdobra a ideia do método para afirmar que, entre as relações criadas por Godard, sustenta-se uma ética relativa tanto à imagem, como ao sentido de história que nos constitui, como sujeitos de um tempo. A ética, neste caso, envolve um modo de ser singular da imagem, somente possível porque pautada por um e mesmo pressuposto: não o de "mostrar aquilo que não se pode ver" (ibidem, p. 167) - e assim aludindo ao binômio do visível e do invisível da imagem -, mas "mostrar apesar daquilo que não se pode ver" (ibidem, grifos do original). A ética, neste caso, implica uma composição comprometida, paradoxalmente, com o que não se deixa ver, mobilizada por uma e mesma questão: como falar de algo sem necessariamente dizê-lo? (ibidem, p. 168).

A perspectiva de discussão de Didi-Huberman implica reconhecer, sobretudo nesta produção, pelo menos, três desdobramentos fundamentais. O primeiro deles relativo ao tempo da imagem, ou seja, diferente do que, a uma primeira vista facilmente cremos, "as imagens sequer estão no presente" (DIDI-HUBERMAN, 2012, p. 213); elas, antes, são sempre anacrônicas. São tempos heteróclitos que a constituem: o passado que delas emana encontrase reconfigurado perante os múltiplos presentes (e suas imanentes configurações) que a olham; perante o futuro, é provavelmente ela quem sobreviverá a nós (já que, em relação a 
ela, não somos mais do que mero elemento de passagem). Em suma, "a imagem tem mais memória e mais futuro do que o ente que a olha". A(s) história(s) do cinema de Godard não se ocupa $(m)$ em desvendar estas camadas temporais da imagem (ou mesmo das imagens que seleciona), mas antes agutizá-las por meio de uma montagem que é, toda ela, intensificação do tempo. Daí que, como resultado, temos nada menos do que o encontro resistente (porque resiste, mas também porque dura) entre temporalidades contraditórias, no qual a história não é mais algo superfície lisa, não é mais campo de conhecimento, mas algo a criar, a imaginar.

Qual associação possível entre A paixão de Joana D’Arc, de Dreyer (1928), Os pássaros, de Hitchcock (1963) e as imagens de arquivo dos bombardeiros e dos corpos vitimados na Segunda Guerra? Que combinação é esta que torna possível juntar o frêmito de crianças assombradas por aves assassinas, o lamento inconsolável das mulheres junto aos mortos e, ainda, o suplício da donzela? O que é isso, afinal, que, num piscar de olhos, transforma o destrutivo dos pássaros naquele dos aviões, a dor em "nada" (como sugere a sobreinscrição na palavra rien) e o heroísmo (Joana D'Arc) como fundo para a pergunta " $\mathrm{O}$ que é o cinema" [Qu'est-ce que le cinéma]? É também ali, neste espaço plural de sentidos, que o entre das imagens dá a ver, que a pergunta tem uma resposta: "nada [rien]", ele não é nada. "O que ele quer" [Que veut-il]? "O que ele pode" [Que peut-il]? "Qualquer coisa" [Quelque chose] - mas um "qualquer coisa" que aponta para uma defasagem, no caso, insidiosamente, para seu silêncio (cegueira?) frente ao inominável da guerra.
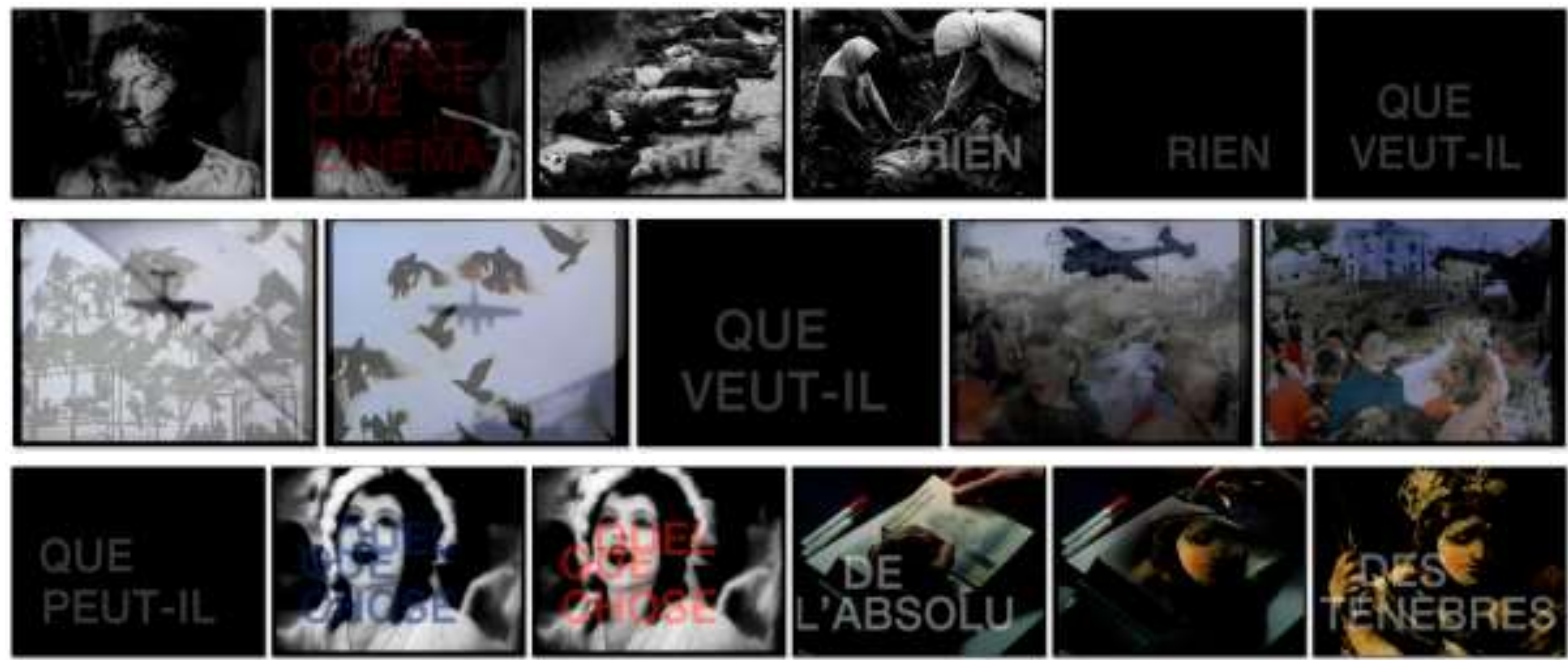

Fonte: Fotogramas extraídos livremente e em sequência direta do filme Histoires(s) du cinéma [1988-1998].

Neste sentido, a montagem, em Histoire(s), não é elemento a ser apagado, tornado imperceptível em prol de sucessões lineares; antes disso, ela é meio que faz ver a própria história como salto, como ruptura, descontinuidade. A montagem faz da imagem, simultaneamente, seu instrumento e objeto; ela é princípio metodológico e operador da imagem. O que se dinamiza em Histoire(s) du cinéma, portanto, é a relação entre a imagem e princípios mais recorrentes sobre seu papel na história e nas formas de narrá-la. O convite sugerido pelo filme parece ser semelhante àquele proposto por Foucault $(2000 \mathrm{a})^{11}$ : não o de

${ }^{11}$ Em A arqueologia do saber, Foucault (2000a, p. 8) apresenta o modo como o método arqueológico propõe uma forma singular de fazer a história, utilizando-se, para tanto, de uma dinâmica entre "documentos" e \begin{tabular}{l|l|l|l|l|l|l} 
(C) ETD - Educ. Temat. Digit. & Campinas, SP & v.18 & n.2 & p.437-457 & abr./jun.2016 & ISSN 1676-2592
\end{tabular} 
transformar os monumentos em imagens, mas, ao invés disso, transformar as imagens em monumentos. Ou seja, não se trata de recuperar, pelas imagens, uma iconografia da história, na qual elas atuariam em favor da comprovação, da recuperação, do reestabelecimento, mas de reconhecer as imagens como pontos de intensificação e concentração de tempos, de relações, de acontecimentos mínimos - por sua vez, suscetíveis a distintas associações, que acabam por contribuir para o sentido sempre móvel e renovado de sua inscrição.

O segundo desdobramento consiste no princípio de que, se se pode dizer que há um trabalho sobre a imagem, é porque a montagem não é mera fusão ou apagamento dos elementos que a constituem; montagem não é construção de um catálogo, afirma DidiHuberman (2003). Ao compor imagens a partir de outras lógicas (que vão do rechaço ao reconhecimento, à interpretação a seu anacronismo inarredável), estamos diante de uma imagem não mais como objeto a conhecer (e, portanto, ao sujeito vidente não corresponde um sujeito cognoscente): ela é espaço onde o não-saber tem lugar. Com efeito, o ato de olhar também não se reduz a uma espécie de dimensão capaz de produzir um conhecimento positivo, muito menos é mecanismo que visa a cognição. Se, como sugere Didi-Huberman (2012, p. 212), todo conhecimento deve conter "um grão de não-sentido", entende-se que há aí algo em suspenso, seja porque sua construção exige um recuo, um movimento que, ao rechaçar a generalização, não se limita ao artefato em si; seja também porque, em sua composição, há um quê de "suspense", algo que demanda forçosamente uma espera, da qual o desenlace ou o fim da imagem não repousa em seus traços materiais (ALLOA, 2015).

É porque nenhuma imagem é capaz de dar conta da história - e, neste caso, não qualquer história, mas a do cinema, da guerra e, sem dúvida, do holocausto - que Godard ultrapassa a "preguiça do esteta" (DIDI-HUBERMAN, 2003, p. 56), radicada na justificativa do "inominável" e do "indizível", que apenas atestariam, na imagem, sua insuficiência. Isto, no fundo, não deixa de ser um dado positivo, já que aponta também para a incapacidade da imagem de qualquer totalização. No entanto, é preciso produzir imagens, apesar de tudo; é preciso ver imagens apesar de tudo (2003) - eis aqui o último desdobramento. O que Godard mostra, então, é que "todas imagens falam somente disso", daí a tornar-se possível um tipo de "lisibilidade": a que se realiza por meio das analogias, dos hiatos, das indeterminações e, ainda, da imaginação. Não há, pois, saber, não há, pois, história, mais uma vez, sem ética, sem implicação, em suma, sem que seja exigido "tomar posição" - o que é diferente de "tomar partido" (DIDI-HUBERMAN, 2009). É justamente o modo como as imagens e seu uso (montagem) respondem às questões que colocamos a elas que apontam para "sua importância - estética e epistemológica - crucial" (idem, 2003, p. 170).

Se trazemos as discussões lançadas por Deleuze e aquelas desdobradas por DidiHuberman é porque elas convergem para o modo como a análise das produções de Godard

\footnotetext{
"monumentos". Assim, se, por um lado, a história, em suas formas mais tradicionais, viria a sedimentar os "monumentos" transformando-os em documentos (ou seja, na qualidade de provas estabilizadoras de um discurso histórico), a história arqueológica, ao contrário, "transforma os documentos em monumentos", ou seja, faz, de cada um deles [dos documentos], um elemento passível de ser recebido como "monumento", em sua marca de acúmulo de relações.
} 
pode sugerir outros caminhos para o estudo sobre o conceito de imagem. Neste caso, trata-se de uma proposição que inscreve o ser da imagem em outro registro de possibilidade de construção de saber. Dizendo de outro modo, uma outra ontologia da imagem se relaciona com outra epistemologia da imagem. Quanto a isso Didi-Huberman (2003, p. 173) mostra que, em Godard, "as imagens se entrechocam para que possam emergir palavras; as imagens e as palavras entram em colisão para que o pensamento tenha lugar visualmente". Ao trazer esta afirmação, não nos referimos apenas à presentificação do texto na imagem (algo já discutido), mas, igualmente, ao efeito e à importância da conjugação entre palavra e imagem e, em seguida, entre imagem-imagem. O efeito: aquele que age em prol de uma proliferação e permanente produção renovada da própria linguagem. Como sugere Didi-Huberman, com base em Benjamin, aos clichês visuais (e, acrescento, aos clichês de montagem) correspondem clichês linguísticos $(2012 ; 2009)$ - escapar dos primeiros incide, assim, na aposta à abertura ao que ainda não tem nome e ao que ainda não se sabe. A importância: a abertura só é possível porque frente às imagens, o sentido não se encontra obstaculizado, mas é, antes, dependente das perguntas (de ordem ética) que cada presente histórico nos impõe ou seja, não se trata, portanto e exclusivamente, de perguntas que um sujeito diretor formulou, mas aquelas cujas respostas somos, também e com ele, convocados a produzir.

\section{CONCLUSÕES}

Podemos dizer que tensionar a categoria de "clássico" por meio da discussão acerca do sujeito enunciador tradicional do cinema (o diretor) foi um dos objetivos deste texto. Ao afirmar que "tensionamos" assumimos que foram estas as categorias que pautaram e orientaram as discussões. No entanto, no lugar de fortalecer os sentidos mais usuais que elas guardam - e que desembocam no discurso da origem, naquele do sujeito da razão -, nosso interesse foi o de elaborar para outras bases para sua compreensão. O esforço foi o de mostrar como algumas produções imagéticas de Godard convidam a outro tipo de olhar no qual: 1) a produção da imagem se consolida num espaço (palavra-imagem) em que se manifesta a dispersão do diretor (e que nos pergunta, afinal, o que é "mesmo" dele); 2) os sentidos são produzidos, em muito, pelo sujeito que olha, já que a imagem, fruto da montagem (imagemimagem) é menos objeto a conhecer e mais superfície de criação. Entre estas duas unidades de análise, um ponto em relevo: corresponderem ao ser da imagem em Godard.

Recuperando a citação de Calvino sobre "por que ler os clássicos", e que dá início a este texto, destacamos o aspecto que aponta para o reconhecimento de uma ruptura, no sentido de que um clássico é algo que faz vibrar, de algum modo, o que vem antes e o que vem depois dele. Ora, fazer vibrar o que o precede implica também supor uma certa continuidade - daí a assumir, como fundamento do debate, a rejeição ao trabalho de caracterizar a produção do diretor no interior do discurso da origem. Ao mesmo tempo, fazer vibrar o que a ele sucede consiste em mostrar como, ao mesmo tempo, sua produção é marcada por uma diferença. Foi a partir desta ruptura, investida de uma descrição não de um ponto de princípio, mas de algo singular - neste caso, um modo de ser da imagem -, que esta discussão se organizou. 
Além disso, perguntar sobre o ser da imagem não se voltou para a tentativa de responder, peremptoriamente, "o que é imagem" - muito menos o que é "uma" imagem. Ao trabalho importou capturar a imagem em sua dinamicidade - algo que não incide em respostas, mas, antes, em possibilidades de pensamento, na renúncia em mostrar qualquer compromisso com a verdade da imagem e com o saber positivo (e categórico) que dela supostamente poderiam emergir. Dizendo de outro modo, apontar para o ser da imagem significou sumarizar alguns de seus modos de existência enquanto espaços possíveis para a criação e recriação de outras relações entre imagem e saber. Afirmamos, assim, que o ser da imagem só se dá em ato; ele é, pois, circunstancial. Percorrer os trajetos que o compõem envolveu algo que talvez se aproxime da própria imagem que Didi-Huberman (2007, p. 19) se utiliza para falar deste esforço: a da imagem-mariposa.

Se realmente quisermos ver as asas de uma mariposa, primeiro, temos que matá-la e, depois, conservá-la em uma vitrine. Uma vez morta, e somente então, podemos contemplá-la tranquilamente. No entanto, se quisermos conservá-la viva - o que, no fundo, seria muito mais interessante -, somente veremos as asas fugazmente, por pouco tempo, num piscar de olhos. Isto é a imagem. A imagem é uma mariposa. Uma imagem é algo que vive e que só nos mostra sua capacidade de verdade numa cintilação.

Obviamente que as questões aqui lançadas estão longe de ser definitivas - até mesmo porque os próprios autores indicados se permitiram reescrever algumas de suas posições ${ }^{12}$. Ao contrário, elas apenas relançam possibilidades outras de inscrever as imagens em nossa cultura - e, talvez mais precisamente, em nossas investigações. É sabido o quanto aqueles que, no campo do cinema e da educação, se empenham em organizar materiais de análise, se deparam com categorias como a de "diretor" ou a de "clássico" (e com tantas outras, relativas, por exemplo, à história do cinema, aos gêneros narrativos). Insistimos, portanto, que, no lugar de assumir tais categorias por si mesmas ou de abandoná-las de imediato, vale, antes, operar sobre elas, tensionando-as, problematizando-as, em suma, fazendo delas operadores teórico-metodológicos. Tal movimento supõe questioná-las ali mesmo onde se tramam seus limites, perguntando, portanto, como elas se instituem, o que as sustenta, quais dinâmicas organizam e como podem incidir em uma potência do pensamento. Ou, o que pode ser equivalente, indagá-las ali mesmo onde esses limites são rompidos, fraturados, dissolvidos em direção a outras discussões.

\section{REFERÊNCIAS}

ALLOA, Emmanuel. Entre a transparência e a opacidade - o que a imagem dá a pensar. In: ALLOA, Emmanuel (Org.). Pensar a imagem. Belo Horizonte: Autêntica, 2015.

\footnotetext{
12 Não há como não mencionar o fato de que, em seus últimos trabalhos, Didi-Huberman (2015) revisita a mesma produção de Godard - Histoire(s) du cinéma - e se questiona, por exemplo, sobre a apropriação das imagens de arquivo e, neste caso, sobre o modo como o diretor imprimiria ali, ao mesmo tempo, um modo muito pessoal e "ostensivamente de posse" sobre elas (ibidem, p. 221) - ainda que "não se compraza de alguma "exploração narcísica"” (ibidem, p. 20).
} 
BORGES, Jorge Luis. Os jardins dos caminhos que se bifurcam. In: BORGES, Jorge Luis. Ficções. São Paulo: Globo, 1989, p. 71-83.

CALVINO, Ítalo. Por que ler os clássicos. Companhia das Letras: São Paulo, 1993.

DELEUZE, Gilles. A imagem-movimento. São Paulo: Brasiliense, 1983.

DELEUZE, Gilles. A imagem-tempo. São Paulo: Brasiliense, 1990.

DELEUZE, Gilles. Conversações. São Paulo: 34, 2000.

DIDI-HUBERMAN, Georges. Devolver uma imagem. In: ALLOA, Emmanuel (Org.). Pensar a imagem. Belo Horizonte: Autêntica, 2015.

DIDI-HUBERMAN, Georges. Quando as imagens tocam o real. Pós, Belo Horizonte, MG, v. 02, n. 04, p. 204-219. nov. 2012. Disponível em: 〈http://goo.gl/zxIyJx $\rangle$. Acesso em: 02 abr. 2016. ISSN 2238-2046.

DIDI-HUBERMAN, Georges. Images malgré tout. Paris: Éditions de Minuit, 2003.

DIDI-HUBERMAN, Georges. Quand les images prennent position. Paris: Éditions de Minuit, 2009.

DIDI-HUBERMAN, Georges. Un conocimiento por el montaje. Entrevista com Georges Didi-Huberman, por Pedro Romero. Revista Minerva, Madrid, Espanha, v. 05, p. 17-22, 2007. Disponível em: 〈http://goo.gl/HA0Xs6 >. Acesso em: 02 abr. 2016. ISSN 0213-9634.

DUBOIS, Phillippe. Cinema, vídeo, Godard. São Paulo: Cosac Naify, 2004.

FOUCAULT, Michel. Arqueologia do saber. Rio de Janeiro: Forense, 2000.

FOUCAULT, Michel. As palavras e as coisas. São Paulo: Martins Fontes, 1999.

FOUCAULT, Michel. O que é um autor. In: FOUCAULT, Michel. Ditos \& escritos III Estética: literatura e pintura, música e cinema. Rio de Janeiro: Forense, 2001, p. 264-298.

FOUCAULT, Michel. Sobre a arqueologia das ciências. Resposta ao círculo de epistemologia. In: FOUCAULT, Michel. Ditos \& escritos II - Arqueologia das ciências e história dos sistemas de pensamento. Rio de Janeiro: Forense, 2000, p. 82-118.

FOUCAULT, Michel. Nietzsche, a genealogia e a história. In: FOUCAULT, Michel. Ditos \& escritos II - Arqueologia das ciências e história dos sistemas de pensamento. Rio de Janeiro: Forense, 2000, p. 260-281.

LEANDRO, Anita. Lições de roteiro, por JLG. Educação e Sociedade, Campinas, SP, v. 24, n. 83, p. 681-701. ago. 2003. Disponível em: 〈http://goo.gl/X2X5o2〉. Acesso em: 02 abr. 2016. ISSN 1678-4626. 
LEANDRO, Anita. Godard contra a adaptação: Carmen e outras histórias do cinema. Aletria

- Revista de Estudos de Literatura, Belo Horizonte, MG, v. 08, p. 60-71. 2001. Disponível em: 〈http://goo.gl/XwVthT>. Acesso em: 02 abr. 2016. ISSN 2317-2096.

MACHADO, Roberto. Foucault, a filosofia e a literatura. Rio de Janeiro: Zahar, 2005.

VASCONCELLOS, Jorge. A pedagogia da imagem: Deleuze, Godard - ou como produzir um pensamento do cinema. Educação \& Realidade, v. 33, n. 01, p. 155-168. jan./jun. 2008. Disponível em: <http://goo.gl/9rWR73> . Acesso em: 02 abr. 2016. ISSN 2175-6236.

\section{PRODUÇÕES CITADAS}

DREYER, Carl. A paixão de Joana D'Arc [La passion de Joanne D'Arc]. Paris: Société générale des films, 110 min., 1928.

GODARD, Jean-Luc. A chinesa [La chinoise]. Paris: Anouchka Films, Les Productions de la Guéville, 96 min., 1967.

GODARD, Jean-Luc. Adeus à linguagem [Adieu au langage]. Paris: Canal Plus, 69 min., 2015.

GODARD, Jean-Luc. Aqui e acolá [Ici et ailleurs]. Sonimage, INA, Paris, 53 min., 1974

GODARD, Jean-Luc. Como vai você [Comment ça va]. Paris: Sonimage, 75min., 1978.

GODARD, Jean-Luc. Histoire(s) du cinéma. Paris: Gaumont, 266 min., 1988-1998.

GODARD, Jean-Luc. Numéro deux. Paris: Bela Productions, Société Nouvelle de Cinématographie (SNC), 88 min., 1975.

GODARD, Jean-Luc. O acossado [À bout de souffle]. Paris: Films Impéria, 90min., 1960.

GODARD, Jean-Luc. O demônio das onze horas [Pierre, le fou]. Paris: Paris Filmes, 110 min., 1965.

GODARD, Jean-Luc. O desprezo [Le mépris]. Paris: Paris Filmes, 103 min., 1963.

GODARD, Jean-Luc. Six fois deux. Paris: INA, 100 min., 1976.

GODARD, Jean-Luc. Tour/detour/deux enfants. Paris: Sonimage, 26 min., 1977-1978.

GODARD, Jean-Luc. Uma mulher é uma mulher [Une femme est une femme]. Paris: Paris filmes, 85 min., 1961.

HITCHCOCK, Alfred. Os pássaros [The birds]. Los Angeles: Alfred J. Hitchcock Productions, 119 min., 1963. 


\section{Como citar este documento:}

MARCELLO, Fabiana Amorim. Jean-Luc Godard e o ser da imagem. ETD - Educação Temática Digital, Campinas, SP, v. 18, n. 2, jul. 2016. ISSN 1676-2592. Disponível em:

<http://periodicos.sbu.unicamp.br/ojs/index.php/etd/article/view/8644733〉. Acesso em: 04 jul. 2016. doi:http://dx.doi.org/10.20396/etd.v18i2.8644733. 